\title{
ISLAMIC SCHOOLS AND SOCIAL JUSTICE IN INDONESIA: A Student Perspective
}

\author{
Raihani $^{1}$ \\ Adjunct Research Fellow at School of Social Sciences, The University of Western \\ Australia, Australia \& Faculty of Islamic Education \& Teacher Training, \\ Sultan Syarif Kasim State Islamic University, Riau, Indonesia
}

\begin{abstract}
:
The study explores how students of two different Islamic Senior Secondary Schools in Palangkaraya, Indonesia experience school practices in regards to social justice. Employing a qualitative approach, the researcher conducted ethnographic observations of the schools' practices and events, and interviewed more than fifty students of the two schools individually and in groups to understand their feelings and perspectives about how the schools promote social justice among them. The findings suggest that several school structures including the subject stream selection, student groupings, the emergence of the model or international classroom were found to have been sources for social injustice. Students of the Social Sciences and Language groups, of low academic performance and economically disadvantaged admitted the feeling of unfair treatment because of this structuration. Confirming the theory of social reproduction, the schools failed to provide distributive, cultural and associational justices, and reasserted further inequalities among members of society.
\end{abstract}

[Artikel ini menjelaskan bagaimana siswa pada dua Sekolah Menengah Atas di Palangkaraya, Indonesia merasakan praktek pendidikan di sekolah mereka, khususnya terkait dengan masalah keadilan sosial. Melalui

1 This paper is one of the outcomes of a project entitled "Education for Tolerant and Multicultural Indonesia” funded by Australia Research Council (ARC) 2009-2012. The project team members include Prof Lyn Parker, Dr CY Hoon, and Dr Raihani. 
studi kualitatif, penulis melakukan observasi etnografis terbadap praktek pendidikan dan kegiatan sekolah serta melakukan wawancara dengan lebih dari lima puluh orang siswa, baik. secara individual maupun dalam kelompok, untuk mengetahui pandangan mereka mengenai bagaimana sekolah mereka mendorong pelaksanaan prinsip keadilan sosial. Artikel ini menemukan bahwa struktur pendidikan di sekolah tersebut, seperti pengelompokan kelas berdasarkan konsentrasi jurusan, pola keberkelompokan siswa, dan munculnya kelas-kelas internasional, menyebabkan ketidakadilan sosial di dalam institusi pendidikan. Siswa kelas Ilmu Sosial dan Babasa cenderung minim dalam pencapaian akademik, dan secara ekonomi berasal dari kalangan menengah ke bawah. Mereka merasakan bahwa sistem pengelompokan kelas yang berlaku melanggengkan ketidakadilan sosial. Selaras dengan teori reproduksi sosial, sekolah tersebut telah gagal mengimplementasikan keadilan distributif, kultural dan asosiasional, dan babkan telah melanggengkan ketidakadilan sosial.]

Keywords: Islamic schools, multicultural, marketization of education

\section{A. Introduction}

After the collapse of the Suharto regime in 1998, Indonesia embarked upon a remarkable policy of educational decentralisation. This followed the implementation of a broader political and financial decentralisation and regional autonomy policy. ${ }^{2}$ Much of the authority and power in education is now delegated to provincial and district players. More substantially, schools have been given greater autonomy in terms of management and curriculum through the programs of school-based management (MBS, Manajemen Berbasis Sekolah) and school-based curriculum (KTSP, Kurikulum Tingkat Satuan Pendidikan) ${ }^{3}$. It is within this context that the study was being conducted.

One of the key characteristics of education for diversity is that it

2 E. Aspinall \& G. Fealy, Local Power and Politics in Indonesia: Decentralisation \& democratisation (Singapore: Institute of Southeast Asian Studies, 2003). C. Bangay, "Private Education: Relevant or Redundant? Private Education, Decentralisation and National Provision in Indonesia," Compare, 35(2), 2005, 167-179.

3 Raihani, Education Reforms in Indonesia. A. Bandur, A Study of The Implementation of School-Based Management in Flores Primary Schools in Indonesia, PhD Unpublished PhD, The University of Newcastle, Australia, Newcastle, 2008. 
is strongly based on the ethos of social justice. Education for diversity strives to translate this into educational programs, strategies, and school cultures where students learn to become socially just citizens. ${ }^{4}$ Every effort to create education for a multicultural society must be underpinned by the principles of equality and solidarity among members of the society, the proper understanding and valuing of human rights, and the recognition of the dignity of every human being. ${ }^{5}$ In this way, education enables pupils to develop themselves to their fullest potential regardless of ethnicity, religion, gender and class. While social justice should be manifest in the process of school education through school policies, school cultures, interactions among pupils and teachers, and the broader school environment, it also becomes one of the objectives, i.e. to produce pupils with social justice awareness and competences in a diverse society. ${ }^{6}$

This paper intends to answer the following questions: 1) Are Islamic schools in Indonesia prepared to become sites for social justice education? 2) In what ways are the school structures supportive of the creation of social justice? and 3) How do school leaders and teachers help to create conditions supportive of social justice? In responding to these questions, this paper presents findings of students' perspectives, based on their experiences of schooling, regarding social justice in the selected madrasah. It analyses contemporary schooling in Indonesia through the "eyes" of students, focusing on school structures such as subject stream choices, student grouping, and the emergence of model or international classroom. Despite the government's campaigns of meritocratic schools where talent and efforts alone predict outcomes, the current context of decentralization has put schools including madrasah in the market logic which in turn leads schools to become places for social reproduction. Schools then reassert further inequalities amongst students of rich and

${ }^{4}$ C. I, Bennet, Comprehensive Multicultural Education, 2nd ed. (Boston: Allyn and Bacon, 1990. Also, C. I, Bennet, "Genres of Research in Multicultural Education," Review of Educational Research, 71(2), 2001, p. 171-217.

${ }^{5}$ J. Zajda, S. Majhanovich \& V. Rust, The Epistemology of Social Justice, in J. Zajda, S. Majhanovich \& V. Rust (eds.), Education and Social Justice: Issues of Liberty and Equality in the Global Culture (Dordrecht: Kluwer Academic Publishers, 2006), pp. 1-12.

${ }^{6}$ J. A. Banks, Educating Citizens in a Multicultural Society (New York: Teacher College Columbia University, 1997). J. Lynch, Multicultural Education (London: Routledge \& Kegan Paul, 1986). 
poor backgrounds. This paper begins by reviewing briefly concepts of social justice both from general and Islamic perspectives, and the theory of social reproduction in education. It will depict the current context of Indonesian education and explain the research methodology. This paper will then present and discuss the findings of students' perceptions and experiences about social justice at schools.

This qualitative study selected two different Islamic schools in Palangkaraya: one is a Muhammadiyah school ${ }^{7}$ named Ibnu Rusydi and the other is MAN al-Najah. ${ }^{8}$ Ibnu Rusydi is a private school that caters students from ethnically diverse backgrounds: Banjar, Java, Dayak, and others. This is a lower to middle class school. In 2010, around 500 students were enrolled in this Islamic school. MAN an-Najah is a high-performing state Islamic school in both academic and non-academic aspects, located several kilometres from the city centre. Its students are largely from urban families of different ethnic backgrounds and various social classes. In 2010, the school enrolled 650 students.

I conducted two stints of fieldwork each lasting two months in the two Islamic schools, in the period 2009 - 2010. The study employed Focus Group Discussions (FGD) and in-depth interviews with more than 50 students, exploring their perspectives on social justice, or injustice, based on their experiences during schooling. I also conducted ethnographic observations of the day-to-day school practices and events. I actually collected information from other important sources including teachers, principals, and parents, but for the purpose of this paper, I only present the perspectives of students for two reasons. One is that students' voices have rarely been heard by the school decision makers, as many studies indicate. 'The other is that the above issues related to social justice or injustice at school are something that can mostly only be

${ }^{7}$ I categorise this Muhammadiyah school into Islamic schools not because of the curriculum, which is a Dikbud (Ministry of Education and Culture) curriculum, but because of its commitment to provide education based on Islamic values. This categorisation is parallel to that of Catholic or Christian school, which is administered under the MoEC, not the Ministry of Religion (MoR).

8 All the names of schools and respondents are pseudonyms.

9 A. Cook-Sather, "Sound, Presence, and Power: "Student Voice" in Educational Research and Reform," Curriculum Inquiry, 36(4), 2006, pp. 359-390. R. Feldman, "Listening to Student Voices," Visual Art Research, 2003, pp. 68-81. 
felt by the "victims", i.e. students who have to accept the culture and/ or their position in the school society.

\section{B. Social Justice and Sociocultural Reproduction}

Education in Indonesia is characterised by a structural dichotomy, in which two schooling systems exist concurrently. The first system consists of general schools, which are administered by Ministry of Education and Culture (MOEC), while the second is comprised of Islamic schools, which are under the administration of Ministry of Religion (MOR). ${ }^{10}$ MOEC's schools are termed as "sekolah" or school, while MOR's ones are referred to as madrasah. There are public schools and public madrasah as well as private schools and private madrasah. Most MOEC's schools are public, while most of MOR's madrasah are private. This fact indicates imbalanced government policies towards the existing schooling in Indonesia between school and madrasah. More funding and favourable policies and practices by Indonesian government throughout its modern schooling history have been given to MOEC's schools. This unfairness, as many have argued ${ }^{11}$, is rooted on the discriminative policies and practices of the Dutch colonials towards Islamic education sectors. Such discrimination has brought about a gap in educational quality between schools and madrasah.

Apart from the dichotomy of secular/general schools and madrasah, there are private schools which characterise themselves as religious schools, such as Catholic and Muhammadiyah schools. This type of school is affiliated to MOEC since they use its required curriculum. However, they use other curricula (formal or non-formal) which are deliberately designed to nurture religious commitment and internalise religious values in students. They integrate additional religious subjects into the MOEC curriculum, and design and organise religious activities for students to undertake in order to flourish beliefs and values in them. In some cases, these schools may become more religious than those under the MOR administration. For the purpose of this paper, I categorise

${ }^{10}$ Raihani, "Education Reforms in Indonesia in The Twenty-First Century," International Education Journal, 8(1), 2007, pp. 172-183.

11 K. A. Steenbrink, Pesantren, Madrasah, Sekolah (Jakarta: LP3ES, 1994); Mujiburrahman, Feeling Threatened: Muslim-Christian Relations in Indonesia's New Order (Amsterdam: Amsterdam University Press/ISIM, 2006). 
Muhammadiyah schools into Islamic schools with a warning to the readers that this school does not use the MOR curriculum. So, Muhammadiyah school remain different from madrasah.

Pertaining to social justice, Cribb and Gewirtz ${ }^{12}$ identify three types of justice - distributive, cultural and associational. Distributive justice is largely concerned with how goods and services are distributed amongst individuals, ${ }^{13}$ and will be possible only if the absence of exploitation, marginalisation, and deprivation can be ensured. Rawls ${ }^{14}$ definition of social justice is one of the main concepts classified in this type. Cultural justice occurs when every culture in society is valued and recognised to the extent that there is no cultural domination and no disrespect to any culture. Associational justice is seen as: "the absence of patterns of association amongst individuals and amongst groups which prevent some people from participating fully in decisions which affect the conditions within which they live and act". ${ }^{15}$ These three types of justice cover issues that may arise among those who are dissatisfied with a broad range of social conditions, including economic, cultural, and political conditions, and relations amongst individuals as well as between groups. Thus, these three types of social justice are concerned not only with individuals in society but also with groups and their relations with others. In short, Greene ${ }^{16}$ believes that social justice is concerned with the basic rights of every human being regardless of economic disparity or class, gender, race, ethnicity, citizenship, religion, age, sexual orientation, disability or health.

In Islam, justice is one of the central themes of its teachings. One verse among many in the Quran said: "Indeed, We sent Our Messengers with clear proofs and revealed with them the Scripture and the Balance

12 A. Cribb \& S. Gewirtz, Towards a Sociology of Just Practices: An Analysis of Plural Conceptions of Justice, in C. Vincent (ed.), Social Justice, Education and Identity (London: RoutledgeFalmer, 2005), pp. 15-29.

13 S. Gewirtz, Rethinking Social Justice: A Conceptual Analysis, in J. Demaine (ed.), Sociology of Education Today (Basingstoke: Palgrave, 2001).

${ }^{14}$ J. Rawls, A Theory of Justice (Cambridge MA: Harvard University Press, 1971), p.3.

15 S. Power \& S. Gewirtz, "Reading Education Action Zones," Journal of Education Policy, 16(1), 2001, pp. 39-51.

${ }^{16}$ M. Greene, Introduction: Teaching for Social Justice, in W. Ayers, J. A. Hunt \& T. Quinn (eds.), Teaching for Social Justice (New York: Teachers College Press, 1998), pp. xxvii-xlvi. 
(justice) that mankind may keep up..." (QS: 57:25). ${ }^{17}$ The concept of justice in Islam encompasses four dimensions of justice, namely socioeconomical, legal, cultural and associational justices. Certain measures are mandated to realise the socio-economic justice through the payment of zakat (alms tax) and the prohibition of usury. In the legal dimension, equality before law is enforced regardless of kinship and backgrounds. The famously quoted Prophet's saying relevant to mention here is "had Fatima the daughter of Muhammad stolen, I would verily cut her hand off" ${ }^{18}$ In terms of cultural justice, the Quran acknowledges differences in culture and encourages human beings to interact positively (QS 49:13), ${ }^{19}$ and also argues that if Allah wanted, He could create only one community (QS 5:48). Islam is also concerned with associational justice as the Quran instructed the Prophet ${ }^{20}$ (QS 3:159) always invite members of the Medina society to discuss matters of which no revelation had been sent.

What is the role of schools as the institutions of formal education in the creation of social justice in society? Social reproduction theory argues that school does not support and teach equal opportunity and social justice as it is a place where most of a culture's dominant discourses are passed on to pupils. ${ }^{21}$ The cultural capital - the advantages that people have as a part of life experiences, peer relationships, and family backgrounds - that schools value is frequently different from that valued by people in their own communities. In a school where pupils come from different backgrounds, the cultural capital of the school is not equally available to them, and is usually the culture of the economically and culturally advantaged or privileged groups in the community. Pupils from working class backgrounds are too often stigmatised and seen to have an inferior form of culture, a kind of anti-knowledge, while middle

17 M. T. Al-Hilali \& M. M. Khan, Interpretation of the Meanings of the Noble Qur'an in the English Language (Riyadh: Maktabah Dar-us Salam, 1994), p. 743.

${ }_{18}$ M. I. Al-Bukhari, Al-Jami' al-Sabih Li al-Bukhari: The Collection of the Valid Prophet's Traditions by al-Bukhari, Vol. 1 (Riyad: Maktabah al-Malik Fahd al-Wataniyah Atsna al- Nashr, 2008), p. 307.

19 Al-Hilali, Interpretation of the Meanings.

${ }^{20}$ Ibid, p. 97.

${ }^{21}$ P. Bourdieu, The Forms of Capital, in J. Richardson (ed.), Handbook of Theory and Research for the Sociology of Education (New York: Greenwood, 1986), pp. 241-258. Also in P. Bourdieu \& J.-C. Passeron, Reproduction in Education, Society and Culture, 2nd ed. (London: Sage, 1990). 
class pupils feel at home because their culture is highly regarded in school policies and processes. Since cultural capital translates into economic and social capital, working class students tend to get working class jobs. ${ }^{22}$ Parallel to the above theory is the concept of the hidden curriculum. Vallance $^{23}$ refers it broadly to the social-control function of schooling in which "a number of processes operating in or through schools, including values acquisition, socialisation, maintenance of class structure." The hidden curriculum implies that schools are sites where pupils learn how to behave in accordance with what society, and then schools, value. Parker's' ${ }^{24}$ studies about schooling in Bali provided some examples of the hidden curriculum, i.e. the teaching of modernity, discipline and well-behaving, and the transmission of the societal beliefs about gender. The idea of hidden curriculum is actually functioned as a device to identify and depict systematic 'side-effects' of schooling which are not explicitly written in the planned curriculum. However, the concept often connotes a negative meaning which is to describe that school practices often promote and reproduce social injustice and inequality amongst students.

\section{Social (in)Justice in Indonesian Islamic Education}

There are several themes emerging from the fieldworks related to social justice in one or both of them. These include the subject stream selection and the student groupings, and the status of religious minority in Ibnu Rusydi. Students I had conversations with through individual and focus group interviews commonly talked about these problematic issues.

Issues of social justice that students of Ibnu Rusydi and an-Najah shared were centred on the subject streams of the schools. Both Islamic schools provided students with three different streams, namely: Natural Sciences (NS), Social Sciences (SS), and Language (LS). At the end of

${ }^{22}$ P. E. Willis, Learning to Labor: How Working Class Kids Get Working Class Jobs (New York: Columbia University Press, 1977).

${ }^{23}$ E. Vallance, Hiding the Hidden Curriculum: An Interpretation of the Language of Justification in Nineteenth-Century Education Reform, in H. Giroux \& D. Purpel (eds.), The Hidden Curriculum and Moral Education: Deception or Discovery? (California: MrCutrhan Publishing Corporation, 1983), pp. 9-27, p. 10.

${ }^{24}$ L. Parker, The Quality of Schooling in A Balinese Village (Indonesia, 1992) 54, pp. 95-116. See also L. Parker, "Engendering School Children in Bali," The Journal of the Royal Anthropological Institute, 3(3), 1997, pp. 497-516. 
Grade X, students are required to select a subject stream according to their talent as demonstrated in their academic achievement in Grade $\mathrm{X}$. The schools also conduct a survey to identify students' academic interest. Those who are strong in maths and natural sciences are strongly encouraged to choose NS, and the rest are 'forced' to choose SS or LS. However, most students preferred NS to the other streams because of the image of science: it was more promising in terms of university choices later on and occupations.

What the schools have done by screening students for NS at the first instance and putting the rest in other streams, what some parents have aspired for their children, and what students prefer for their next study are not independent from certain images, reputations, and prestige that were constantly associated with each stream. What most frequently heard from the studied schools were the images that NS graduates will have better jobs and make more money in the future like medical doctors, while SS will not. Also, NS is for high intelligent and obedient students, while SS and LS are for those who failed in the NS selection. SS students were consistently portrayed as disobedient and indiscipline students; very frequently they were called "anak buangan" (reject students). Unfortunately, some teachers played a significant role in preserving such images and, hence, impressing discriminative actions to students.

Raihani: What do you think about your teachers' attitudes towards NS, SS or other groups?

Endang: Not good. I don't want to say bad about my teachers, but teachers here don't care [about us].

Budi: We feel differentiated. Yes, we feel it.

Susilo: More severe than that, Sir, is [that] they discriminated between NS and SS students. To be honest, SS students feel marginalised. Some of them said SS [students] are like reject students (FGD with Ibnu Rusydi students).

Students of the two schools also described some teachers being temperamental or lazy when teaching in non-NS class. While the teachers might not be aware of their negative attitude and its implications on students' psychological and social conditions, most students did take notes about this and developed the feeling of liking or disliking. The 
competitions in a negative sense such as mocking each other amongst students of different streams was also intensified partly because of such teachers' unsupportive attitudes and behaviours. It seemed that SS and LS students suffered most from this unfair structuration. The absence of teachers of these two streams for various reasons was almost an everyday scene particularly in Ibnu Rusydi. Although some of these teachers left assignments for students to do during their absence, it could not keep students from escaping from classrooms. They spent happily this "spare time" at the school canteen or made an early finish if the teacher's absence happened to be in the final hour of the day. Extra-ordinary indiscipline behaviour was seen almost every day in these schools.

Student grouping is another controvesial issue that students of particularly in an-Najah brought forward in the conversations. Ibnu Rusydi students were overwhelmed by the issues related to the subject streams, and did not mention at all about this grouping. An-Najah consisted of seven groups of Grades X and XI respectively and six of Grade XII. Both schools implemented a similar strategy in grouping students, which divided Grade X students using the results of the school entry test or ability grouping. ${ }^{25}$ Simply, students were grouped from higher to lower ranks in Grades X1, X2, and so forth. As a result, Grade X1 classroom was a place for the most highly performing students.

In an-Najah, there were two exclusive groups in each grade the students of which were selected on the grounds of intelligence and wealth - ability-wealth grouping. These groups were called as "kelas modeP" (model groups) serving the school's ambition to produce small groups of brilliant individuals. Grade X students of this kind were projected to choose NS later in Grade XI. These groups enjoyed more complete and 'luxurious' multimedia learning facilities and smaller class size - 25 compared to 35-40 - whilst others did not. Almost all the regular kind of students interviewed expressed critical perspectives about these groups:

To me, this kind of grouping should not be existent so that we [students] can be more comfortable in our relationship. We should not group this is rich and this is not (Laili, FGD, an-Najah).

${ }^{25}$ M. Plunkett, "Re-Conceptualizing Ability Grouping Within A Social Justice Framework: A Student Perspective," The Australasian Journal of Gifted Education, 18(2), 2009, pp. 5-16. M. T. Hallinan, "Ability Grouping and Student Learning," Brookings Papers on Education Policy(6), 2003, pp. 95-140. 
The above account reflects the failure of the school to create social justice among different backgrounds of students. They were not given an equal opportunity, equal facilities, and equal quality of teachers to guide them to realise their aspirations. Thus, different outcomes between intelligent/rich students and slow/poor students could not be justified due to different processes that the school provided.

In addition to the above, the status of minority students in schools is always a contentious issue in the discourse of education for diversity and social justice. ${ }^{26}$ Ibnu Rusydi was not an exception. Although it is owned privately by an Islamic organisation and categorised as an Islamic school, it had three Protestant students enrolled. The existence of this minority in this school provided an invaluable opportunity for the community of the school to interact with religious others.

The policies in Ibnu Rusydi did not entirely demonstrate a keen promotion of social justice amongst students of different religions. The three Protestant students were not required to attend Islamic religion class nor provided with a proper instruction of Protestantism. The compulsory provision of religion classes of every student as mandated in the 2003 Education Law did not seem to be enforced to private schools ${ }^{27}$ including Ibnu Rusydi. One perhaps valid reason was that the number of minority students was too small, and hence too costly, to arrange a religion class. So, Ibnu Rusydi only required the minority students to attend the corresponding religious services in their community Churches, and obtained the assessment outcomes from the priests. Trying to understand this policy, John -one of the minority students- said:

We cannot study our religion here because there is no Protestant teacher provided by the school. The principal said to us that there is no funding to cover the cost of such a class.

${ }^{26}$ R. Kaymakcan, Curriculum and Textbook Revisions Regarding the Image of "Religious Other" in Turkish Religious Education, in R. Kaymakcan \& O. Leirvik (eds.), Teaching for Tolerance in Muslim Majority Societies (Istanbul: DEM: Center for Values Education, 2007), pp. 16-31. R. Kaymakcan \& O. Leirvik (eds.), Teaching for Tolerance in Muslim Majority Societies (Istanbul: DEM: Centre for Values Education, 2007).

27 L. Parker, "Religious Tolerance and Inter-Faith Education in Indonesia," Paper presented at the Crises and Opportunities: Proceedings of the 18th Biennial Conference of the ASAA, Adelaide, 2010. Also Raihani, "Religion Classes in Indonesia: Translating Policy into Practice," Paper presented at the Crises and Opportunities: Proceedings of the 18th Biennial Conference of the ASAA, Adelaide, 2010. 
Raihani: Are you obliged to join Islamic religion class, then?

John: Yes, even though the school policy did not put it compulsory on us. The [Islamic class] teacher requires us to observe the class because she is worried about what we would be doing outside during the class.

What John said indicates an inconsistency between school policy and teacher's classroom practices in regards to the provision of religion classes for minority students. This also suggests the lack of recognition of their real existence within the school society, a manifest of cultural injustice. $^{28}$ The cases above also show structural marginalisation by the schools as social institutions which caused the feeling of being discriminated in students, even though the relationship amongst peer students was found to have been fluid, dynamic and harmonious. The classical justification for this policy is that the schools did not possess sufficient funds to cover the costs of the compulsory religion classes for minority as explained by the principal of Ibnu Rusydi. He said: "organising one religion class for only three students will cost us a lot of money equal to doing that for 30 to 40 students. It is very expensive, and we can't afford it".

However, as shown in Ibnu Rusydi, there seems to be not only a matter of financial issues in dealing with religious minority students, but also understanding of their basic rights as religious individuals. The school has made wearing "jilbab" compulsory as well on non-Muslim female student. Rita told a story of how she felt degraded when she had to wear "jilbab" for the first time. She said:

I was shocked for the first time, even though I knew before I decided to choose this school. I felt that I am being converted to Islam. I learnt it [wearing jilbab] gradually. And now I am getting used to it.

Although Rita was not converted to Islam in the school, she could not hide an uncomfortable experience and situation she has been in for a couple of years in the school. Ibnu Rusydi, therefore, has failed to protect its student's basic rights to be respected on the basis of her own faith.

In the following sentences, I would like to address the above

${ }^{28}$ N. Fraser, Justice Interuptus: Critical Reflections on the 'Postsocialist' Condition (New York and London: Routledge, 1997). E. Frazer, Citizenship Education: Anti-Political Culture and Political Education in Britain, in W. C. Parker (ed.), Education for Democracy: Contexts, Curricula, Assessments (Connecticut: Information Age Publishing, 2002). 
details in the lights of the implementation of social justice and the indonesian education reform. As the Minister of National Education said, ${ }^{29}$ Indonesian education has demonstrated a significant improvement in the school participation rate. Almost every school-aged child, particularly at primary level, is given an equal opportunity to attend school. ${ }^{30}$ The question, however, is whether education has been able to provide an equal opportunity for every child to experience good quality of schooling because, as Banks ${ }^{31}$ argues, the inclusion of pupils of different backgrounds in schools does not necessarily mean that they experience equal quality. The current study has shown that there are problematic issues about how social justice is promoted in the studied schools. These issues can be localised within three main dimensions of schooling, i.e. education policies, school structures, and teachers' understanding about social justice and their roles in its creation in the school context.

\section{Education Policies}

As mentioned above, since 1999, Indonesia has undergone a major education decentralisation which provides an ample opportunity for localities to play significantly more active roles. This decentralisation requires more active community participation in education. ${ }^{32}$ Under

29 B. Andalan, "Mendiknas Klaim Pendidikan Indonesia Sukses: Jumlah Peserta Didik di Indonesia Terbesar Ketiga di Asia," vivanews.com, June 5, 2011. Retrieved from http://us.nasional.vivanews.com/news/ read/224683-mendiknas-klaim-pendidikan-indonesia-sukses.

30 The 2008 Statistics indicated that the participation rate of primary schoolaged students reached $98.9 \%$, while those of junior secondary and senior secondary school-aged students were figured at $85.5 \%$ and $56.8 \%$ respectively. This indicates that the government's program of nine-year compulsory education was quite successful, but might indicate that almost half of the secondary school-aged students' parents cannot afford senior secondary education for their children as free education is only implemented to primary and junior secondary levels.

31 J. A. Banks, Multicultural Education and Its Critics: Britain and the United States, in S. Modgil, G. K. Verma, K. Mallick \& C. Modgil (eds.), Multicultural Education: The Interminable Debate (London: The Falmer Press, 1986), pp. 221-231. J. A. Banks, Multicultural Education: Development, Paradigms and Goals, in J. A. Banks \& J. Lynch (eds.), Multicultural Education in Western Societies (London: Holt, Rinehart and Winston, 1986), pp. 2-28.

32 C. Bjork (ed.), Educational Decentralization: Asian Experiences and Conceptual Contributions (Dordrecht: Springer, 2006). D. A. Rondinelli, J. R. Nelson \& G. S. Cheema, 
this heated theme of community participation, ${ }^{33}$ school committee has been erected in every school as mandated by laws (Nos 25/2000 and 20/2003) for school stakeholders to come into play within the school arena. This committee of state schools, particularly at senior secondary level, is by law allowed to draw fund from parents to support school operations. This permissibility to draw funds from parents was benefited by an-Najah to develop two exclusive model classrooms in each grade. Through this model group policy, it intended to accommodate middle to high social classes of parents who aspired for good education for their children. This is a marketization of education ${ }^{34}$ which has created social segments within the single school; there are groups of rich and intelligent students who enjoyed the privileges of having classrooms, each completed with relatively luxurious learning facilities on one side, and lower class and low performing students who powerlessly accepted their fate of occupying classrooms with only basic learning facilities on the other. The impacts were on their psychological and social wellbeings such as feeling inferiority to model group fellows and, hence, selecting friends according to the social segments or classes. Also, in a more macro context, despite the outcries criticising the policy, we can see that the program of international standard school has seemed to go in a direction to play a significant role in widening the gap between the rich and the poor.

\section{School Structures}

School social structures, such as the stream divisions and abilitywealth groupings in the studied schools have impacted on social justice. These structures and their systematically associated images have "locked" students within a social system where equal opportunity and "Decentralization in Developing Countries: A Review of Recent Experience. Wahington DC: World Bank," Staff Working Paper No. 581, 1984.

${ }^{33}$ L. Parker \& Raihani, Policy Briefs: Governing Madrasah (Canberra: Australia Indonesia Governance Research Partnership (AIGRP)-The Australian National University, 2009. Raihani, Best Practices of SBM: Community Participation in school in Indonesia, in Z. Sakhiyya, I. M. A. Arsana \& M. Ramadewi (eds.), Education Counts (Yogyakarta: Yogyakarta Insight Media, 2011), pp. 39-58.

${ }^{34}$ L. Bartlett, M. Frederick, T. Gulbrandsen \& E. Murillo, "The Marketization of Education: Public Schools for Private Ends," Anthropology and Education Quarterly, 33(1), 2002, pp. 5-29. 
justice are luxuries they cannot afford. The culture developed within this system was appropriated more for students from the higher social class backgrounds. ${ }^{35}$ The non-privileged students were forced to live within this differentiating culture and powerlessly to accept it. Some of interviewed students were indeed aware of these 'suppressing' structures, and therefore struggled to free themselves from the associated images of the structures - playing agency. ${ }^{36}$ They, as change agents, want to reform the existing marginalising structures. Giddens maintains that structure and agency are interdependent as there cannot be agency without structures, and structures cannot be separated from social actors who change and create them. In short, the above mentioned social structures within the schools are in fact changeable.

Another aspect of this school structure is in regards to the status of religious minority in the school. As explained above, Ibnu Rusydi's policies on religious minority students are not favourable to them. There is a deliberate incompliance in Ibnu Rusydi to the national policy of the provision of corresponding religion classes for students as mandated in the Education Law of 2003. The case demonstrates further that there is a lack of recognition to religious differences among students. This confirmed other findings in a Catholic school in Palangkaraya where religious minority rights are being "hijacked" by the school on the name of the school's vision and missions.

\section{Teachers' Awareness and Understanding}

The changes of the social structures within the two schools will not effectively occur without supports and active roles of school leaders and teachers. ${ }^{37}$ The present study suggests that school leaders and teachers played no trivial role in creating and maintaining the unsupportive structures. Teachers' conscious or unconscious behaviours of imaging particular groups or streams as previously presented have helped create segregations amongst students. The above cases also indicate that there

35 Bourdieu and Passeron, Reproduction in Education, Society.

${ }^{36}$ L. Parker, (ed.), The Agency of Women in Asia (London: Marshall Cavendish Academic, 2005). A. Giddens, The Constitution of Society: Outline of the Theory of Structuration (Oxford: Polity Press, 1984). A. Giddens, Sociology, 4th ed. (Oxford: Blackwell Publishing, 2001.

${ }^{37}$ M. Fullan, Change Forces: The Sequel (Philadelphia: Falmer Press, 1999). 
is still much to improve in terms of teachers' understanding, skills and competences particularly in dealing with students of different backgrounds. The ability grouping will indeed make the teaching process much easier for teachers to imparting lessons. ${ }^{38}$ Plunkett's ${ }^{39}$ study, which reveals that both higher and lower ability groups of students "perceived their educational experience as both appropriate and positive and that neither considered themselves disadvantaged," provides support for this ability grouping. However, many studies show some disturbing tendencies that higher ability students are given higher quality instruction, a more challenging curriculum, and a more teaching time than those of lower ability groups. ${ }^{40}$ This means that higher ability students have more opportunities to learn than the lowers. The current research found other impacts of the ability grouping and ability-wealth grouping including discriminative behaviours by teachers such as being easily tempered and frequent absences in the lower ability groups, group competitions among students, and feeling inferiority of the lower ability students. What makes the impacts of this grouping worse is that there are obvious differentiations between groups by the school such as the provision of learning facilities because of different school payments.

\section{Conclusion}

Ibnu Rusydi and an-Najah have not yet become sites for the effective promotion of social justice among students. The social reproduction theory is accepted. The severe dichotomy of NS and other streams, the ability-wealth groupings and the status of religious minority students have implicated on the provision of distributive justice to students. Students did not equally receive what they were entitled to as members of the school community. The failure to provide distributive justice had domino effects on the provision of associational justice to students as they started to make inclusion and exclusion in their social interactions. As a result, students of less favoured groups from SS and LS experienced feeling of inferiority and marginalisation that impeded

38 J. Oakes, Keeping Tracks: How Schools Structure Inequality (London: Yale University Press, 1985).

39 M. Plunkett, "Re-Conceptualizing Ability Grouping," p. 5.

40 M. T. Hallinan, 2003, D. Clarke \& B. Clarke, 2008, "Is time up for ability grouping?," http:// cmslive.curriculum.edu.au/leader/default.asp?id=22535\&issueID 
them from equal participation in social interactions and activities. It is also obvious that cultural justice has not fully come to the attention of Ibnu Rusydi particularly in relation to their policies of religious minority students. The schools failed to fully acknowledge their existence as equally significant as the majority. The minority students consequently suffered from distributive injustice particularly in terms of the provision of classroom for their religion classes. In this study, the three types of justice i.e. distributive, cultural and associational are found to be interconnected in that one can lead to another.

The injustice experienced by students is partly a manifest of the hidden curriculum, which has seemingly missed the attention of the schools' leaders and teachers. The policies and practices on the issues of subject streaming, student grouping, and religious minority students have institutionalised in students certain values which contributed to shaping their minds in perceiving the social realities. These values include the necessity of social and class differences, the powerless acceptance of such differences, and differences consequently lead to different fates. An economically disadvantaged student of an-Najah with average academic performance had to accept the reality that he or she was grouped with other students of similar economical and academic status. These values embedded in the school practices might not be part of the written curriculum, but they might have a more powerful effect in shaping students' minds and attitudes. ${ }^{41}$ This is a kind of the embodied cultural capital ${ }^{42}$ that effectively translated in the schools' milieu, and is not in the light of Islamic teachings despite the majority of population that the study is concerned with was Muslims. An-Najah which is in itself an Islamic school and Ibnu Rusydi which is under an Islamic organisation have failed to translate the Islamic teachings of distributive, cultural and associational justice.

At last, I would like to put forward several recommendations for the schools in order to refine policies and practices in regards to the promotion of social justice among students. First, there should be a strong vision for transforming the schools to become ideal places for students

${ }^{41}$ H. Giroux \& D. Purpel (eds.), The Hidden Curriculum and Moral Education: Deception or Discovery (California: MrCutrhan Publishing Corporation, 1983).

42 P. Bourdieu, "The Forms of Capital," in J. Richardson (ed.), Handbook of Theory and Research for the Sociology of Education (New York: Greenwood, 1986), pp. 241-258. 
to experience justice and equality through the program of multicultural education. Second, to this end there should be a systemic reform, as the opposite of sporadically unplanned one, in several school dimensions, i.e. vision and policies, leadership and management, curriculum and teaching, capacity and cultures, student activities and collaboration with wider community. As where to start is always the question, my third recommendation is that school leaders would play a pivotal role in directing and orchestrating the reform agenda. This has been evident in the large body of knowledge across the globe. ${ }^{43}$ The subsequent element is that to ensure that knowledge and skills are developed and shared within the schools corresponding to the vision for multicultural education. Thus, the fourth recommendation is to foster professional development of teachers and other staff to increase their awareness of social diversity and justice and to develop their competences in teaching and making appropriate evaluation within the framework of multicultural education. Finally, I would like to echo the people's and experts' outcries in regards to model classrooms (kelas model), which is designed to be the impetus of international standard schools (SBI, Sekolah Berstandar Internasional), that the central government needs to reconsider the program as the concept is not convincingly clear to improve Indonesian education as a whole and its impacts on the possibly increasing segregations of society. The teachings of justice of Islam and other religions should be taken into account in the school policy making process, and do not stop as a mere slogan.

${ }^{43}$ K. Leithwood, "Understanding Successful School Leadership: Progress On A Broken Front," Journal of Educational Administration, 43(6), 2005, pp. 619-629. T. J. Sergiovanni, Handbook for Effective Department Leadership: Concepts and Practices in Today's Secondary Schools, 2nd ed. (Boston: Allyn \& Bacon, 1997). 


\section{BIBLIOGRAPHY}

Al-Bukhari, Muhammad b. Ismail, al-jāmi' al-Sahỉh, edited by Abdul Qadir Syaibah al-Hamad, three vols, vol. 2, Riyad: Maktabah al-Malik Fahd al-Wataniyah Athna al-Nashr, 2008.

Al-Hilali, Muhammad Taqiuddin and Muhammad Muhsin Khan, Translation of The Meanings of The Noble Qur'an in The English Language, Madinah: King Fhad Complex for the Printing of the Holy Qur'an, n.d.

Andalan, Boby, "Mendiknas Klaim Pendidikan Indonesia Sukses: Jumlah Peserta Didik di Indonesia Terbesar Ketiga di Asia," vivanews.com, June 5, 2011.

Aspinall, Edward and Greg Fealy, Local Power and Politics in Indonesia: Decentralisation \& Democratisation, Singapore: Institute of Southeast Asian Studies, 2003.

Bandur, Agustinus, A Study of the Implementation of School-Based Management in Flores Primary Schools in Indonesia, The University of Newcastle, Australia, 2008.

Bangay, Colin, "Private Education: Relevant or Redundant? Private Education, Decentralisation and National Provision in Indonesia," Compare 35, no. 2, 2005, p. 167-79.

Banks, James A, "Multicultural Education and Its Critics: Britain and The United States," in Sohan Modgil, Gajendra K. Verma, Kanka Mallick and Celia Modgil (eds), Multicultural Education: The Interminable Debate, London: The Falmer Press, 1986.

----, "Multicultural Education: Development, Paradigms and Goals," in James A. Banks and James Lynch (eds.) Multicultural Education in Western Societies, London: Holt, Rinehart and Winston, 1986.

----, Educating Citizens in A Multicultural Society, New York: Teacher College Columbia University, 1997.

---- (ed.), The Routledge International Companion to Multicultural Education, New York and London: Routledge Taylor \& Francis Group, 2011. Bartlett, Lesley, Marla Frederick, Thaddeus Gulbrandsen, and Enrique Murillo, "The Marketization of Education: Public Schools for Private Ends," Anthropology and Education Quarterly, 33, no. 1, 2002, 
pp. 5-29.

Bennet, Christine I., Comprehensive Multicultural Education, 2nd ed., Boston: Allyn and Bacon, 1990.

----, "Genres of Research in Multicultural Education," Review of Educational Research 71, no. 2, 2001, p. 171-217.

Bjork, Chris (ed.), Educational Decentralization: Asian Experiences and Conceptual Contributions, Dordrecht: Springer, 2006.

Bourdieu, Pierre, “The Forms of Capital," in J. Richardson (ed.), Handbook of Theory and Research for The Sociology of Education, New York: Greenwood, 1986.

----, and Jean-Claude Passeron, Reproduction in Education, Society and Culture, 2nd ed., London: Sage, 1990.

Clarke, Doug, and Barbara Clarke, "Is Time Up for Ability Grouping?," Curriculum Leadership, 2008.

Cook-Sather, Alison, "Sound, Presence, and Power: "Student Voice" in Educational Research and Reform," Curriculum Inquiry 36, no. 4, 2006, p. 359-90.

Corson, David, Changing Education for Diversity, Buckingham: Open University Press, 1998.

Cribb, Alan, and Sharon Gewirtz, "Towards A Sociology of Just Practices: An Analysis of Plural Conceptions of Justice," in Carol Vincent, (ed.), Social justice, education and identity, London: RoutledgeFalmer, 2005.

Feldman, Rhoda, "Listening to Student Voices," Visual Art Research, 2003, p. 68-81.

Fraser, Nancy, Justice Interuptus: Critical Reflections on The 'Postsocialist' Condition, New York and London: Routledge, 1997.

Fullan, Michael, Change Forces: The Sequel, Philadelphia: Falmer Press, 1999.

Giddens, Anthony, The Constitution of Society: Outline of The Theory of Structuration, Oxford: Polity Press, 1984.

----, Sociology, 4th ed., Oxford: Blackwell Publishing, 2001.

Giroux, Henry, and David Purpel (eds.), The Hidden Curriculum and Moral Education, California: MrCutchan Publishing Corporation, 1983. 
Hallinan, Maureen T, “Ability Grouping and Student Learning," Brookings Papers on Education Policy, no. 6, 2003, p. 95-140.

----, and Aage B Sorensen, "Ability Groupings and Student Friendship," American Educational Research Journal 22, no. 4, 1985, p. 485-99.

Kaymakcan, Recep, "Curriculum and Textbook Revisions Regarding The Image of 'Religious Other' in Turkish Religious Education," in Recep Kaymakcan and Oddbjorn Leirvik (eds.), Teaching for Tolerance in Muslim Majority Societies, Istanbul: DEM: Center for Values Education, 2007.

----, and Oddbjorn Leirvik (eds.), Teaching for Tolerance in Muslim Majority Societies, Istanbul: DEM: Centre for Values Education, 2007.

Leithwood, K., "Understanding Successful School Leadership: Progress on A Broken Front," Journal of Educational Administration 43, no. 6, 2005, p. 619-29.

Lynch, James, Multicultural Education, London: Routledge \& Kegan Paul, 1986.

Mujiburrahman, Feeling Threatened: Muslim-Christian Relations in Indonesia's New Order, Amsterdam: Amsterdam University Press/ISIM, 2006.

Oakes, J., Keeping Tracks: How Schools Structure Inequality, London: Yale University Press, 1985.

Parker, Lyn, “The Quality of Schooling in A Balinese Village," Indonesia 54, 1992, p. 95-116.

----, "Engendering School Children in Bali," The Journal of the Royal Anthropological Institute 3, no. 3, 1997, p. 497-516.

---- (ed.), The Agency of Women in Asia, London: Marshall Cavendish Academic, 2005.

----, "Religious Tolerance and Inter-faith Education in Indonesia," Paper presented at the Crises and Opportunities: Proceedings of the 18th Biennial Conference of the ASAA, Adelaide, 2010.

---- and Raihani, Policy briefs: Governing Madrasah, Canberra: Australia Indonesia Governance Research Partnership (AIGRP)-The Australian National University, 2009.

Plunkett, Margaret, "Re-conceptualizing Ability Grouping within A Social Justice Framework: A Student Perspective," The Australasian Journal 
of Gifted Education 18, no. 2, 2009, p. 5-16.

Power, S, and Sharon Gewirtz, "Reading Education Action Zones," Journal of Education Policy 16, no. 1, 2001, p. 39-51.

Raihani, "Education Reforms in Indonesia in The Twenty-first Century," International Education Journal 8, no. 1, 2007, p. 172-83.

----, "Religion Classes in Indonesia: Translating Policy into Practice," in Michael Barr, Gerry Groot, Purnendra Jain, Peter Mayer and Elizabeth Morrell (eds.), Crises and Opportunities: Proceedings of the 18th Biennial Conference of the $A S A A$, Adelaide: Canberra: Asian Studies Association of Australia (ASAA) Inc and the University of Adelaide, 2010.

----, Best Practices of SBM: Community Participation in School in Indonesia, in Zulfa Sakhiyya, I Made Andi Arsana and Mikha Ramadewi (eds.), Education Counts, Yogyakarta: Yogyakarta Insight Media, 2011.

----, "A Whole-school Approach: A Proposal for Education for Tolerance in Indonesia," Theory and Research in Education 9, no. 1, 2011, p. 23-39.

Rawls, John, A Theory of Justice, Cambridge MA: Harvard University Press, 1971.

Rondinelli, D. A., J. R. Nelson, and G. S. Cheema, "Decentralization in Developing Countries: A Review of Recent Experience," Staff Working Paper No. 581, Washington DC: World Bank, 1984.

Sergiovanni, Thomas. J., Handbook for Effective Department Leadership: Concepts and Practices in Today's Secondary Schools, 2nd ed., Boston: Allyn \& Bacon, 1997.

Steenbrink, Karel. A., Pesantren, Madrasah, Sekolah, Jakarta: LP3ES, 1994.

Stones, Rob, Structuration Theory, Hampshire: Palgrave Macmillan, 2005.

Vallance, Elizabeth, "Hiding The Hidden Curriculum: An Interpretation of The Language of Justification in Nineteenth-Century Education Reform," in Henry Giroux and David Purpel (eds.), The Hidden Curriculum and Moral Education: Deception or Discovery?, California: MrCutrhan Publishing Corporation, 1983.

Willis, Paul E., Learning to Labor: How Working Class Kids Get Working Class Jobs, New York: Columbia University Press, 1977. 
Wong, Jocelyn Lai-ngok, "The Effects of Local Intrepretation of Decentralization Policy on School Autonomy in Guangdong Province of China," in Christopher Bjork (ed.), Educational Decentralization: Asian Experiences and Conceptual Contributions, Dordrecht: Springer, 2006.

Zajda, Joseph, Suzanne Majhanovich, and Val Rust, "The Epistemology of Social Justice," in Joseph Zajda, Suzanne Majhanovich and Val Rust (eds.), Education and Social Justice: Issues of Liberty and Equality in The Global Culture, Dordrecht: Kluwer Academic Publishers, 2006. 
Raihani 